\title{
A COMPARISON OF LANDSCAPE MULCHES: CHEMICAL, ALLELOPATHIC, AND DECOMPOSITION PROPERTIES
}

\author{
by Mary L. Duryea, ${ }^{1}$ R. Jeffery English, ${ }^{2}$ and L. Annie Hermansen ${ }^{3}$
}

\begin{abstract}
This study compared chemical, allelopathic, and decomposition properties of 6 mulches: cypress, eucalyptus, pine bark, pine needle, melaleuca, and a utilitytrimming mulch (GRU). Eucalyptus and GRU mulches had the highest decomposition after 1 year $(21 \%$ and $32 \%$ ), while only $3 \%$ to $7 \%$ of the other mulches decayed. Lignin and lignin:nitrogen ratio were negatively correlated with decomposition; high values resulted in low decomposition. Winter respiration of both eucalyptus and GRU mulches was high, and respiration was positively correlated with decomposition. Pine-straw mulch subsided from $9 \mathrm{~cm}(3.5 \mathrm{in}$.) to $4 \mathrm{~cm}$ (1.6 in.) during the year, while the other mulches subsided approximately 2 $\mathrm{cm}(0.8 \mathrm{in})$. Nutrient composition of the mulches was significantly different, with GRU mulch having the highest levels of calcium $(\mathrm{Ca})$, magnesium $(\mathrm{Mg})$, nitrogen $(\mathrm{N})$, phosphorus $(\mathrm{P})$, and potassium $(\mathrm{K})$. Pine straw was the next highest in $N$ and $P$. Soils under the mulches were acidified most by pine straw (from a pH of 5.0 to 4.4), followed by pine bark and cypress. In a standard test of allelopathy, all fresh mulches inhibited germination of lettuce seed, and although variable in concentration, all mulches contained hydroxylated aromatic compounds that could have caused these allelopathic effects. After 9 months and 1 year, pine straw and GRU still exhibited allelopathic effects on germination. Cypress, melaleuca, and pine bark retained their color after 1 year, while the other 3 mulches changed to a pinkish gray.
\end{abstract}

Key Words. Decomposition rates; mulch; allelopathy; landscaping; lignin; nutrients; respiration.

Mulching trees, shrubs, and other plants plays an important role in the survival and health of the urban forest (Fraedrich and Ham 1982; Green and Watson 1989). Mulches are known to buffer soil temperature (Ashworth and Harrison 1983; Stinson et al. 1990; Greenly and Rakow 1995) and prevent water loss from the soil by evaporation (Watson 1988; Stinson et al. 1990; Gleason and Iles 1998). They also may inhibit weed germination and suppress weed growth (Borland 1990; Stinson et al. 1990; Skroch et al. 1992; Greenly and Rakow 1995).
The soil protection provided by a mulch prevents wind and water erosion, and the incorporation of mulch may increase organic matter of the soil and therefore its tilth and structure (Borland 1990; Black et al. 1994). These benefits and the increasing interest in mulching have resulted in a wide array of mulches available for the gardener and landscaper.

Landscape mulches are either organic or inorganic. Inorganic mulches include gravel, pebbles, or polyethylene film (Black 1994). Typical organic mulches are composed of wood, bark, or leaves singly or in combination. Cypress mulch, for instance, is composed mostly of wood (heartwood and sapwood) with some bark. Pine-bark mulch has mostly bark with a small fraction of wood. Pine straw consists of pine needles from long-needled eastern and southern pine trees. There is much interest in recycling yard waste and utility prunings, and these mulches are very heterogeneous in both the type of tree species and plant parts (leaves, branches, wood, and bark) included. Recently, tree species such as eucalyptus and cypress have been planted in plantations specifically for mulch production. Another recent interest is the eradication and disposal of undesirable invasive species by cutting and mulching trees such as melaleuca in Florida.

These mulches are often purported by producers to be superior to their counterparts either in durability, color, or composition. However, very little research has been done comparing them. Some of the questions that arise are: What is the chemical composition of these different mulches? Are they toxic to plants or specifically to weeds? How fast do various mulches decompose? Do some mulches retain their color longer? How is the soil (e.g., pH) under mulch affected? This study set out to answer some of these questions for 6 typical landscape mulches in the eastern United States. 


\section{METHODS \\ General}

Six tree-based landscape mulches were compared: 1) cypress (wood from Taxodium distichum [L.] Rich. and Taxodium distichum var. nutans [Ait.] Sweet); 2) eucalyptus (wood from Eucalyptus grandis W. Hill ex Maiden); 3) melaleuca (wood from Melaleuca quinquenervia [Cav.] S.T. Blake); 4) pine bark (from Pinus elliottii [Engelm.] and P. taeda [L.]); 5) pine straw (needles from $P$. elliottii [Engelm.]); and 6) Gainesville Regional Utility (GRU) mulch. The GRU mulch contained utility prunings from oaks (Quercus laurifolia Michx., Q. rubra [L.], and Q. virginiana Mill.) and cherry (Prunus serotina Ehrh.), with a small amount of cedar and pine (Juniperus silicicola [Small] Bailey) and southern pines (Pinus spp.). All mulches (except the GRU utility-pruning mulch) were purchased at garden stores in Gainesville, Florida, either by the bag or bale (pine straw).

The study was installed on July 15, 1997. For decomposition and subsidence measurements, we installed plastic rings filled with mulch; these remained undisturbed for 1 year (see Decomposition and Subsidence section below). Wood frames ( $1.2 \times$ $1.2 \mathrm{~m}[4 \times 4 \mathrm{ft}])$ were installed to take measurements for soil and mulch chemical characteristics and color, and for allelopathy, nutrients, lignin, and respiration. These frames were filled with mulch to a depth of $9 \mathrm{~cm}$ (3.5 in). The experimental design included 5 blocks in a randomized complete block design $(5$ blocks $\times 6$ mulches $=30$ frames $)$.

\section{Chemical Composition of the Mulch}

Chemical composition of the mulches was also measured. Initial $\mathrm{P}, \mathrm{K}, \mathrm{Mg}$, and $\mathrm{Ca}$ of each mulch was analyzed using a sulfuric acid digest run on an ICAP (Inductive Coupled Argon Plasma) spectrometer. Carbon $(\mathrm{C})$ and nitrogen $(\mathrm{N})$ were measured initially and after 6 months using a Carlo Erba NCS 2500 Elemental Analyzer, and the C:N ratio was calculated. Klason lignin (defined as acid-insoluble material volatilized by heating at $\left.575^{\circ} \mathrm{C}\left[1,066^{\circ} \mathrm{F}\right]\right)$ and total carbohydrates were analyzed on single samples (no replication) sent to the USDA Wood Products Laboratory in Madison, Wisconsin. Initially and at 6 months, acidsoluble lignin was analyzed at the University of Florida using the Van Soest method (Goering and Van
Soest 1970); the lignin: $N$ ratio was calculated. Hydroxylated aromatic compounds were analyzed initially for each mulch using the colormetric method described by Kloster (1974) and approved by the Standard Methods Committee (1985).

\section{Chemical Composition of the Soil}

To determine the influence of mulches on soil chemistry, we initially measured $\mathrm{pH}$ and Mehlich I extractable phosphorous ( $\mathrm{P})$, potassium $(\mathrm{K})$, magnesium $(\mathrm{Mg})$, and calcium $(\mathrm{Ca})$ of the soil within each wood frame. After 1 year, we measured soil $\mathrm{pH}$ to determine if changes had occurred under the mulch.

\section{Respiration}

We measured respiration $\left(\mathrm{CO}_{2}\right.$ evolution) of each mulch to predict the rate of decomposition. In each frame, we installed 2 clear canisters $(20 \mathrm{~cm}$ high $\times$ $11 \mathrm{~cm}$ diameter $=1,900 \mathrm{~cm}^{3}[7.9 \mathrm{in}$. high $\times 4.3 \mathrm{in}$. diameter $=116$ in. $\left.^{3}\right)$ each containing mulch at a depth of $9 \mathrm{~cm}(3.5 \mathrm{in})\left(854 \mathrm{~cm}^{3}\left[52 \mathrm{in.}^{3}\right]\right)$. On 4 dates, 6 weeks apart, we sampled the $\mathrm{CO}_{2}$ in each canister using an ADC Model LCA3 Infrared Gas Analyzer (IRGA). Air temperatures were also recorded each hour during measurements. We destructively sampled the mulches in the canisters at the end of the 4.5-month measurement period and oven dried and weighed the mulch to express $\mathrm{CO}_{2}$ evolution per gram dry weight.

\section{Decomposition and Subsidence}

To compare the decomposition of the 6 mulches, we installed plastic rings $(26.5 \mathrm{~cm}$ [10.5 in.] in diameter) with mulch $9 \mathrm{~cm}$ (3.5 in.) deep $\left(5,000 \mathrm{~cm}^{3}\left[305 \mathrm{in.}^{3}{ }^{3}\right)\right.$ in a plowed open field at the Austin Cary Memorial Forest near Gainesville, Florida. The experimental design included 16 blocks in a randomized complete block design ( 16 blocks $\times 6$ mulches $=96$ rings). We determined the initial dry weight of each mulch by taking eight $5,000 \mathrm{~cm}^{3}$ samples, oven drying samples for 72 hours at $70^{\circ} \mathrm{C}\left(158^{\circ} \mathrm{F}\right)$, weighing them, and calculating an average weight for each mulch. Initial bulk density was also determined. Every 3 months, subsidence of the mulches was measured by recording the height of the mulch within each ring. After 1 year, the mulches were extracted from the rings, and oven dry weight was measured to determine decomposition. We calculated the total weight of mulch remain- 
ing and the percentage of mulch lost (decomposed). Eight blocks were harvested after 1 year; the remaining 8 blocks will be harvested after 2 years.

\section{Allelopathy}

Allelopathy is the inhibition of seed germination and growth of plants through the release of chemicals. We used a common method to measure allelopathy by extracting watersoluble chemicals from the mulches and then applying this extract to germinating lettuce seeds. To make the extract, we placed $250 \mathrm{~mL}$ of tightly packed mulch in a $600-\mathrm{mL}$ beaker with $300 \mathrm{~mL}$ of distilled water. The mulch was soaked for 72 hours at $27^{\circ} \mathrm{C}\left(80.5^{\circ} \mathrm{F}\right)$ and the extract was filtered with a funnel and filter paper. Four $\mathrm{mL}$ of extract was applied to filter paper in $85 \times 15 \mathrm{~mm}$ petri dishes $(3.3 \times 0.6$ in.), and 30 lettuce seeds were placed in each dish. The petri dishes were sealed with Parafilm ${ }^{\circledR}$ and placed in a Percival ${ }^{\circledR}$ I 30-L growth chamber with a continuous fluorescent light regime and constant temperature of $24^{\circ} \mathrm{C}$ $\left(75^{\circ} \mathrm{F}\right)$ for 5 days. After 5 days, we recorded the number of germinants for each mulch extract. The randomized complete block design included 5 blocks $\times 7$ extracts $(6$ mulches +1 distilled water control treatment) $\times 3$ petri dishes $=105$ petri dishes for each experiment. The allelopathy experiment was conducted quarterly using mulch sampled from the decomposing mulches in the wood frames.

\section{Color}

To determine the color changes of the mulches, we determined their colors initially and then quarterly using Munsell ${ }^{\circledR}$ Color Charts (1975 edition).

\section{Statistical Analyses}

All data (except the lignin and carbohydrates from the USDA Laboratory) were subjected to analysis of variance using SAS (Statistical Analysis System, SAS Institute, Cary, NC). All percentages were analyzed as untransformed values. Plots of residuals versus fitted values demonstrated a random scatter of the data

points showing that transformation of the data was not necessary. We then employed a Tukey's Studentized Range Test for each variable and calculated a Minimum Significant Difference at the 95\% confidence level.

\section{RESULTS AND DISCUSSION Chemical Composition of the Mulch}

The chemical composition of mulches determines their quality as food for decomposer organisms (Swift et al. 1979). The 3 main groups of compounds that influence the mulch's desirability as a food source are 1) carbon and energy sources, 2) nutrient sources, and 3) chemicals that might inhibit or stimulate decomposer activity (Swift et al. 1979). In general, among the carbon and energy sources, the first to be decomposed are the carbohydrates (sugars), followed by the cell wall polysaccharides (cellulose and hemicellulose) and lastly the lignin (Swift et al. 1979, p. 136). Total carbohydrate levels of our 6 mulches were cypress (55\%), eucalyptus (54\%), melaleuca (51\%), GRU (50\%), pine bark (42\%), and pine straw (35\%). With these results, we might predict that pine bark and pine straw would not decompose as much due to their low carbohydrate food quality. 

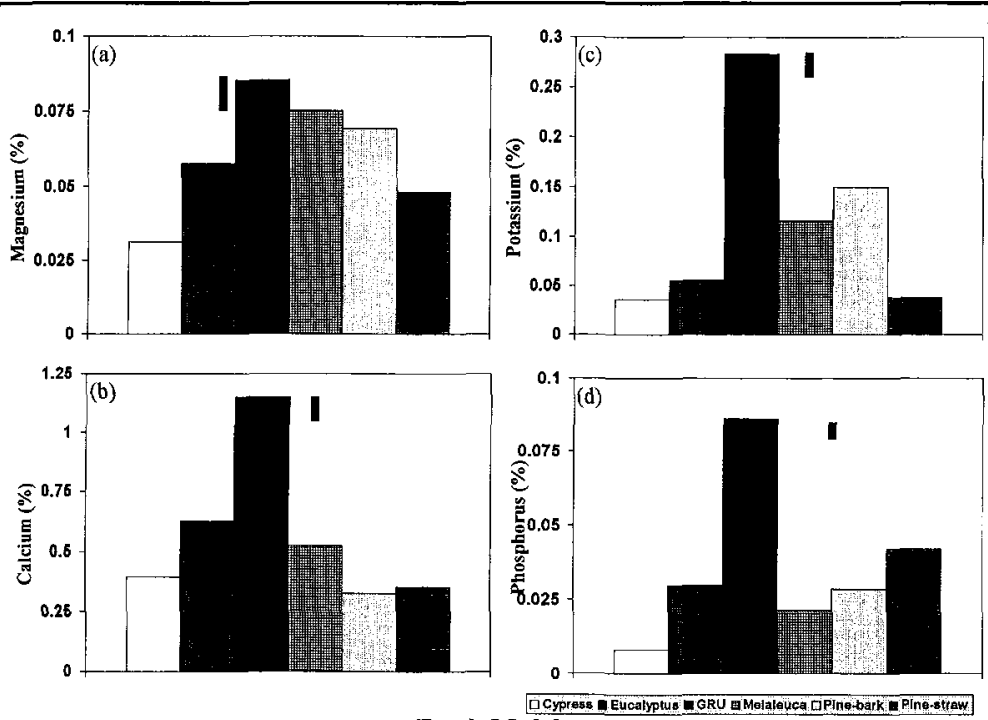

Fresh Mulches

mulches in $\mathrm{Ca}, \mathrm{Mg}, \mathrm{K}, \mathrm{P}$, and $\mathrm{N}$ (Figures $2 \mathrm{a}-\mathrm{d}$ and Figure $\mathrm{lb}$ ). The inclusion of green leaves in the mulch meant no resorption of nutrients by the trees (as in the autumn before leaf (all), thereby providing an extra boost of nutrients for the decomposers. Pine straw was the next richest in both $\mathrm{P}$ and $\mathrm{N}$. Pine bark was especially high in $\mathrm{Mg}, \mathrm{K}$, and $\mathrm{N}$. Cypress mulch had the lowest nutrient concentrations. Taking into account these initial nutrient levels alone, one would predict GRU and pine straw to have the highest decomposition rates. Cypress would have the slowest decomposition rate because it is the poorest nutritional food source for decomposers.

High ratios of lignin: $N$ and $C: N$

Figure 2. Percent magnesium (a), calcium (b), potassium (c), and phosphorus (d) in 6 fresh mulches. (Bars represent Tukey's Minimum Significant Difference at $P=0.05$.)

Lignin is the most important feature of mulches and litters and has been used as an index to predict decomposition of litter in forests (Meentemeyer 1978; Swift et al. 1979). The higher the lignin, the more recalcitrant the material is to decomposition. In both the USDA Wood Products Laboratory and University of Florida laboratory analyses, high lignin concentrations were found in pine bark and pine straw followed by cypress, melaleuca, GRU, and eucalyptus (Figure 1a).

Based solely on these lignin concentrations, we would predict that pine bark and pine straw would decompose the slowest, followed by cypress and melaleuca, with eucalyptus and GRU decomposing the fastest. One study of leaf litter from 5 different species showed a highly significant negative correlation $\left(r^{2}=0.89\right)$ between the amount of lignin and amount of decomposition (Cromack 1973), signifying that those species with more lignin decomposed less.

Nutrient elements provide a necessary food source for decomposer microorganisms. In general, the highest concentrations of nutrients are found in deciduous leaf-litter, followed by conifer leaves and lastly woody tissues (Swift et al. 1979). In agreement with these results, the GRU utility-trimming mulch was significantly higher than any of the other rates (Meentemeyer 1978). Because lignin: $\mathrm{N}$ was high for both cypress and pine bark, these mulches may have low decomposition rates due to the undesirable lignin and the low $\mathrm{N}$ as a food source for microorganisms (Figure 1c). Decomposition of eucalyptus and GRU mulches might be high due to their low lignin: $N$ ratios. The $C: N$ ratio is yet another indicator of decomposition potential, and cypress, melaleuca, and eucalyptus were all high, followed by pine bark (Figure 1d). Both pine-straw and GRU mulches had the lowest lignin: $N$ and $C: N$ ratios, indicating that their decomposition rates might be high.

Chemicals, especially of an aromatic nature, may negatively influence the activity of decomposer organisms (Swift et al. 1979). Phenolic substances in the heartwood of trees have been shown to be the principal means of decay resistance (Scheffer and Cowling 1966). Hydroxylated aromatic compounds (also referred to as "tannin-like compounds") were highest in the GRU mulch, followed by eucalyptus and cypress, indicating perhaps some potential inhibition of decomposition (Figure 3). The lowest levels were in melaleuca, pine bark, and pine straw. These compounds may also be useful in predicting or explaining the allelopathic effects discussed in the Allelopathy section. 


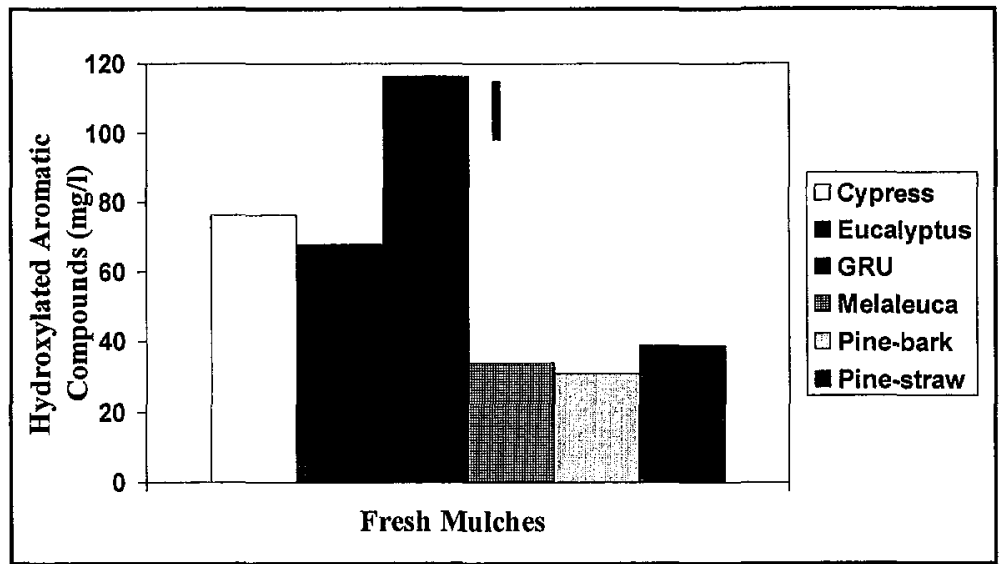

Figure 3. Concentrations of hydroxlated aromatic compounds in 6 fresh mulches. (The bar represents Tukey's Minimum Significant Difference at $P=0.05$.)

\section{Chemical Composition of the Soil}

The soil began with an average $\mathrm{pH}$ of $5.0,1.5 \mathrm{ppm} \mathrm{P}$, 17.0 ppm K, 21.3 ppm Mg, and 107.7 ppm Ca. At the end of 1 year, the soil $\mathrm{pH}$ was the most acidic under the pine-straw mulch (4.4) $(P=0.0001)$. Soils under eucalyptus, GRU, and melaleuca had the highest $\mathrm{pH}, 4.8,4.7,4.7$, respectively, and cypress and pine bark were in the mid-range, 4.6 and 4.6. In contrast, Stinson et al. (1990) found no differences in soil pH under 15 mulches after 6 months. Greenly and Rakow (1995) reported no differences in soil pH under pine versus hardwood wood chips. Over a 4year period, wood-chip mulch accompanied by applications of ammonium sulfate acidified soils (from 6.7 to 5.8) around white oak trees (Quercus alba) (Himelick and Watson 1990).

\section{Respiration}

Respiration measurements were taken beginning in the summer at $32^{\circ} \mathrm{C}\left(90^{\circ} \mathrm{F}\right)$ air temperature and ending in the winter at $18^{\circ} \mathrm{C}\left(64^{\circ} \mathrm{F}\right)$ (Figure 4). In the August summer heat, eucalyptus, GRU, and pinestraw mulches were respiring at faster rates than both cypress and pine bark. In the cooler fall and winter months, eucalyptus and GRU respired the fastest. Pine bark and cypress consistently had the lowest respiration rates throughout the summer, fall, and winter months. Cypress' respiration was also low, especially compared to the eucalyptus and GRU mulches. Using respiration alone, these results would indicate that eucalyptus and GRU mulches would decompose the fastest, while pine bark and cypress would decay the slowest.

\section{Subsidence and Decomposition}

Although we spread the mulches as evenly as a landscaper would, the mulches began with extremely different bulk densities $(P=0.0001)$. From highest to lowest, bulk densities were melaleuca $\left(0.14 \mathrm{~g} / \mathrm{cm}^{3}\right)$, GRU (0.12), pine bark $(0.11)$, cypress $(0.10)$, eucalyptus (0.08), and pine straw (0.02).

By the end of the first 3 months, all of the mulches had subsided at least a centimeter (Figure 5). However, melaleuca (which started with the highest bulk density) had settled the least. Melaleuca, cypress, eucalyptus, and pine bark continued for 12 months to exhibit the least subsidence. Although GRU mulch started with a high bulk density, it showed more subsidence at 12 months than all other mulches except pine straw. Pine straw started with the lowest bulk density and settled from $9 \mathrm{~cm}$ (3.5 in.) deep to $4 \mathrm{~cm}$ (1.6 in.) deep at 12 months. In a study that compared 15 organic mulches, leaf mulches (grass, oak, and pine needles) had the greatest subsidence,

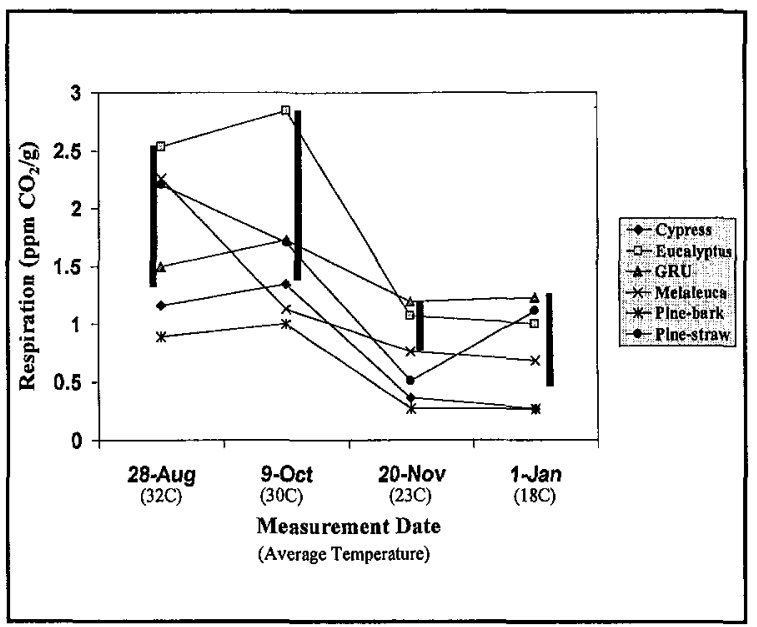

Figure 4. Respiration of 6 mulches at 4 dates. (Average temperature during each measurement period is in parentheses.) (Bars represent Tukey's Minimum Significant Difference at $P=0.05$.) 


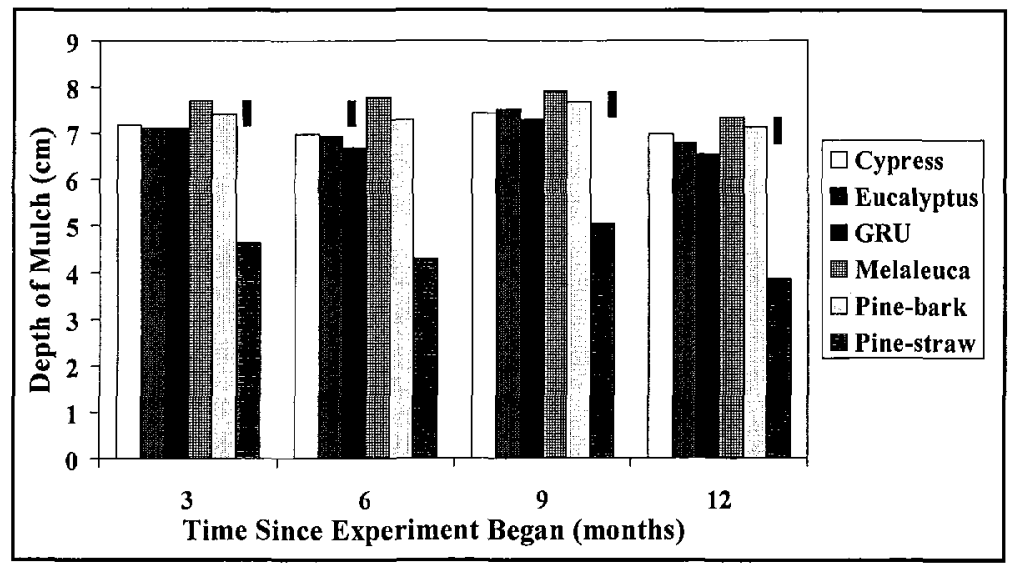

Figure 5. Subsidence of 6 landscape mulches (from the original depth of $9 \mathrm{~cm}[3.5 \mathrm{in}$.$] ) during the 1-year study. (Bars represent$ Tukey's Minimum Significant Difference at $P=0.05$.)

along with 2 yard-waste mulches (Stinson et al. 1990). In another study, cypress settled the least, followed by eucalyptus, melaleuca, and pine straw (Brown 1996). Mulches that have leaves will settle more than woody mulches. Stinson's study (1990) also noted that mulches expand and contract perhaps due to moisture content or animal activity; we noted that during the winter the mulches had less subsidence (Figure 5, see subsidence at 9 months).

Decomposition is a good measure of how long mulches will last. After 1 year, $21 \%$ and $32 \%$ of the eucalyptus and GRU mulches had decomposed. The other mulches had very low decomposition (from $3 \%$ to $7 \%$ ) (Figure 6). Studies in the southern United States of pine needle decomposition in the forest showed an average decay rate of $15 \%$ mass loss per year (Gholz et al. 1985). In another study of decomposition in 10 different ecosystems, decay after 5 years was 2 to 4 times greater for a hardwood species (Drypetes glauca) than for red pine (Pinus resinosa) (Gholz et al. 1998). Northeastern U.S. pine needles decayed $18 \%$ to $30 \%$ each year (Maclean and Wein 1978; Fahey 1983). Mixed hardwood leaf and branch litter in the northeastern United States. had decay rates of $30 \%$ to $60 \%$ each year (Gosz et al. 1973), comparable to the high decomposition rates of GRU mulch, which was composed of hardwood species. In our study, the mulches were exposed to full sunlight, in contrast to the moist forest floor, possibly resulting in a lower moisture content throughout the year. This would result in lower de- composition rates compared to usual forest litter rates.

Of all the variables measured, the lignin: $N$ ratio had the highest correlation $(r=-0.88)$ with decomposition $(P=0.02)$ showing that as the lignin: $\mathrm{N}$ ratio increases, decomposition of mulch decreases. As lignin increased, decomposition also decreased $(r=-81)(P=0.05)$. Lignin concentration has repeatedly been shown to be an excellent predictor of decay rates in forest litter (Meentemeyer 1978; Gholz et al. 1998). Winter respiration was also strongly correlated with decomposition $(r=0.87)(P=0.03)$. Eucalyptus and GRU mulches had the highest respiration rates in November and January, showing active year-round decomposition, compared to cypress and pine bark, which had very low winter respiration. One other significant correlation was for hydroxylated aromatic compounds $(r=0.86)(P=$ 0.03 ), showing an increase in decomposition with increased concentrations of these compounds.

\section{Allelopathy}

Substances in plants may inhibit seed germination or the growth of other plant species; this is called allelopathy. Chemical compounds may be released from mulch by 3 possible mechanisms: 1) volatilization of chemicals from plant parts, 2) leaching of growth in-

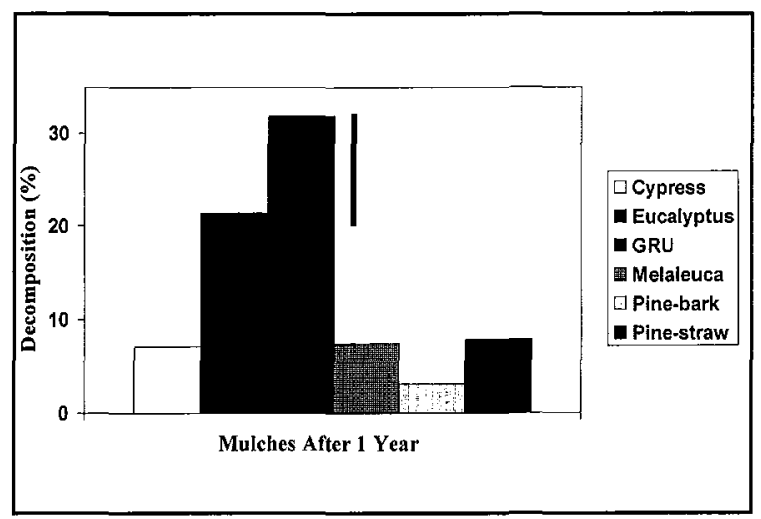

Figure 6. Decomposition (percentage of mass lost) of 6 mulches after 1 year. (The bar represents Tukey's Minimum Significant Difference at $P=0.05$.) 
hibitors from plant parts, and 3) decay of plant tissues, which releases chemicals. One caution with allelopathic experiments is that the concentrations of chemicals that are often tested in the laboratory may not be the same as those accumulating or leaching out in the field (Kramer and Kozlowski 1979). In this study, water extracts from the fresh and the 3-monthold eucalyptus, melaleuca, and pine-straw mulches inhibited germination of lettuce seeds (Figure 7). The GRU and pine-bark extracts had a slight inhibitory effect on germination, while cypress was less inhibiting. Extracts from each mulch collected in the winter (January 15,1997 ) did not exhibit any inhibitory effect on germination. By spring and again with l-yearold mulch, GRU and pine straw were the only significant inhibitors $(P=0.0001)$. The presence of hydroxylated aromatic compounds in all 6 fresh mulches and the demonstrated inhibition of germination by fresh mulch extracts suggests that, at least initially, all the mulches have allelopathic properties to some degree. With mulches, allelopathic properties could have 2 possible impacts: 1) a mulch might inhibit germination of weed seeds, or 2) a mulch might inhibit growth of landscape plants. After 1 year in the field, there was no difference in the number of weeds growing in any of the mulches. The study comparing 15 organic mulches showed less weed growth with

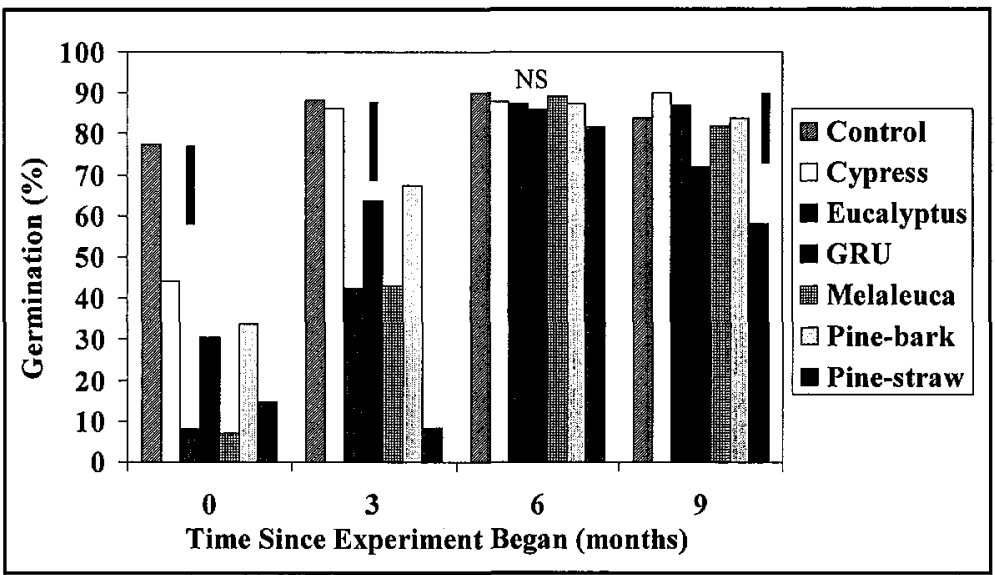

Figure 7. Germination percentage of lettuce seeds exposed to extracts from 6 mulches and distilled water in the control. These allelopathic measurements were taken for fresh mulch ( 0 months) and every 3 months during the year. (Bars represent Tukey's Minimum Significant Difference at $P=0.05$; NS means no significant difference.) mulches compared to bare soil but no difference between all the mulches tested (Stinson et al. 1990). Studies to determine the allelopathic impact of mulches on landscape plants should be continued to determine their potential in weed control or as landscape plant growth inhibitors.

\section{Color}

The ability to retain color is an important factor affecting the landscaper's decision about which mulch to use. The 6 mulches in this study started with colors ranging from pink cypress to the browns of other mulches (Table 1). Cypress mulch retained its pink color for 1 year. Melaleuca changed from a dark reddish brown to gray and pink within 1 year. Eucalyptus, GRU, and pine straw all changed to pinkish gray. Pine bark retained its reddish brown color throughout the year. In a 6-month study, municipal yard waste began to gray after 6 months, while cypress, pine bark, and pine straw all retained their color (Stinson et al. 1990). A study comparing bark mulch to plastic mulches rated bark to have the highest appearance rating after 5 months (Ashworth and Harrison 1983).

\section{CONCLUSIONS}

Utility-pruning and yard-waste mulches are commonly recycled for landscape mulch. These mulches break down faster than other mulches. They may provide more nutrients to landscape plants and improve soil tilth sooner than the other slowerdecomposing mulches. The results from our study also show that a few cautions are in order when using utility-pruning or yard-waste mulches. Because they decompose faster than commercial mulches, they will need to be replenished sooner. Also, these mulches are very heterogeneous, with many different tree species and plant parts, and so have a higher probability of containing some allelopathic properties. Finally, these mulches may contain weed seeds, so an initial composting treatment may be necessary.

Pine straw is rich in $\mathrm{N}$ and $\mathrm{P}$, and these nutrients could be leached and 
Table 1. Color of mulches from the beginning of the experiment ( 0 months) to the end (12 months). Colors were determined from Munsell ${ }^{\circledR}$ Color Charts (1975 edition).

\begin{tabular}{|c|c|c|c|c|c|}
\hline \multirow[b]{2}{*}{ Mulch } & \multicolumn{4}{|c|}{ Color (months since start of experiment) } & \multirow[b]{2}{*}{12} \\
\hline & 0 & 3 & 6 & 9 & \\
\hline Cypress & Pink & Reddish yellow & Pink & Light brown & Pink \\
\hline Eucalyptus & $\begin{array}{l}\text { Light reddish } \\
\text { brown }\end{array}$ & Pinkish gray & Pinkish gray & Light gray & Pinkish gray \\
\hline GRU & $\begin{array}{l}\text { Olive, very pale } \\
\text { brown, pink }\end{array}$ & $\begin{array}{l}\text { Light reddish } \\
\text { brown }\end{array}$ & Pinkish gray & very pale brown & Pinkish gray \\
\hline Melaleuca & $\begin{array}{l}\text { Dark reddish } \\
\text { brown }\end{array}$ & Pinkish gray & Pink & Light gray & Pink \\
\hline Pine bark & $\begin{array}{l}\text { Reddish brown, } \\
\text { light brown }\end{array}$ & $\begin{array}{l}\text { Dark reddish } \\
\text { brown }\end{array}$ & Reddish brown & Brown & Reddish brown \\
\hline Pine straw & Reddish brown & Reddish brown & Reddish gray & $\begin{array}{l}\text { Light brownish } \\
\text { gray }\end{array}$ & Pinkish gray \\
\hline
\end{tabular}

pear to be the best all-round mulches. If the landscaper is interested in nutrient release from the mulch, pine straw and the utility mulch might be considered. Lignin, lignin: $\mathrm{N}$, and respiration were the best predictors of decomposition. This study is being continued for a second year, and pilot studies are underway to investigate allelopathic effects on plants in the landscape. taken up by landscape plants. However, pine straw also may acidify the soil, so liming or the use of acidloving plants may be necessary. Although its decomposition rate was slow, pine straw subsided the most; this could result in more weeds growing through the mulch in the second year. A new layer of pine-straw mulch may be needed in the second year.

Some of the mulches in this study were richer in nutrients than others. The GRU mulch, which had the highest levels of all nutrients, decomposed the fastest. However, high levels of nutrients could also mean nutrient leaching from leaves and branches and consequently increased availability for landscape plants. Also, during decomposition, more nutrients could be released for plant use. Studies of forest litter decomposition have shown that nutrients are released from litter by leaching (e.g., $K$ and $\mathrm{Mg}$ ) and by decomposition (e.g., Ca) (Gosz et al. 1973). Mulches have been shown to increase soil nutrient levels (Tukey and Schoff 1963). These highnutrient mulches might be favorable in conditions where fertilizers are unavailable or not used.

Allelopathic effects of mulches could be positive (weed control) or negative (inhibiting growth or survival of landscape plants). However, caution must also be employed when interpreting laboratory results for the landscape. Because all of the mulches in our study had some allelopathic laboratory effects initially, long-term field studies to test the impacts on landscape plants are needed.

Taking into account subsidence, decomposition, allelopathy, soil $\mathrm{pH}$, and color change results during the first year, cypress, melaleuca, and pine bark ap-

\section{LITERATURE CITED}

Ashworth, S., and H. Harrison. 1983. Evaluation of mulches for use in the homegarden. HortScience 18(2): 180-182.

Black, R.J., E.F. Gilman, G.W. Knox, and K.C. Ruppert. 1994. Mulches for the landscape. Florida Cooperative Extension Service Fact Sheet ENH 103. University of Florida, Gainesville, FL. 4 pp.

Borland, J. 1990. Mulch. Am. Nurseryman August:132-143.

Brown, S. 1996. Response of Hibiscus to organic mulches. Proc. Fl. Hortic. Soc. 109:30-33.

Cromack, K. 1973. Litter production and decomposition in a mixed hardwood watershed and a white pine watershed at Coweeta Hydrologic Station, North Carolina. Ph.D. Thesis. University of Georgia, Athens.

Fahey, T.J. 1983. Nutrient dynamics of aboveground detritus in lodgepole pine (Pinus contorta ssp. latifolia) ecosystems, southeastern Wyoming. Ecol. Monogr. 53:51-72.

Fraedrich, S.W., and D.L. Ham. 1982. Wood chip mulching around maples: Effect on tree growth and soil characteristics. J. Arboric. 8(4):85-89.

Gholz, H.L., C.S. Perry, W.P. Cropper, Jr., and L.C. Hendry. 1985. Litterfall, decomposition, and nitrogen and phosphorous dynamics in a chronosequence of slash pine (Pinus elliottii) plantations. For. Sci. 31:463-478.

Gholz, H.L., S. Smitherman, D. Wedin, and M.E. Harmon. 1998. Toward a global model of long-term litter decomposition, p 61. In abstract presented at the Ecological Society of America Annual Meeting. Baltimore, MD.

Gleason, M.L., and J.K. Iles. 1998. Mulch matters. Am. Nurseryman February:24-31.

Goering, H.K., and R.J. Van Soest. 1970. Forage fiber analyses (apparatus, reagents, procedures, and some applications). ARS USDA Handbook No. 379. Government Printing Office, Washington, DC. $20 \mathrm{pp}$. 
Gosz, J.R., F.E. Likens, and F.H Bormann. 1973. Nutrient release from decomposing leaf and branch litter in the Hubbard Brook Forest, New Hampshire. Ecol. Monogr. 43:173-191.

Green, T.L., and G.W. Watson. 1989. Effects of turfgrass and mulch on the establishment and growth of bareroot sugar maples. J. Arboric. 15(11):268-272.

Greenly, K.M., and D.A. Rakow. 1995. The effect of wood mulch type and depth on weed and tree growth and certain soil parameters. J. Arboric. 21(5):225-232.

Himelick, E.B., and G.W. Watson. 1990. Reduction of chlorosis with wood chip mulch treatments. J. Arboric. 16:275-278.

Kloster, M.B. 1974. Determination of tannin and lignin. J. Am. Water Works Assoc. 66:44.

Kramer, P.J, and T.T. Kozlowski. 1979 Physiology of Woody Plants. Academic Press, New York, NY. 811 pp.

Maclean, D.A., and R.W. Wein. 1978. Weight loss and nutrient changes in decomposing litter and forest floor material in New Brunswick Forest stands. Can. J. Bot. 56:2730-2749.

Meentemeyer, V. 1978. Macroclimate and lignin control of litter decomposition rates. Ecology 59(3):465-472.

Scheffer, T.C., and E.B. Cowling. 1966. Natural resistance of wood to microbial deterioration. Ann. Rev. Phytopath. 4:147-170.

Skroch, W.A., M.A. Powell, T.E. Bilderback, and P.H. Henry. 1992. Mulches: Durability, aesthetic value, weed control, and temperature. J. Environ. Hortic. $10(1): 43-45$.

Standard Methods Committee. 1985. Standard Methods for the Examination of Water and Wastewater. 16 $6^{\text {th }}$ Edition. American Public Health Association, Washington, DC.

Stinson, J.M., G.H. Brinen, D.B. McConnell, and R.J. Black. 1990. Evaluation of landscape mulches. Proc. Fl. St. Hortic. Soc. 103:372-377.
Swift, M.J., O.W. Heal, and J.M. Anderson. 1979. Decomposition in Terrestrial Ecosystems. University of California Press, Berkeley and Los Angeles, CA. 372 pp.

Tukey, R.B., and E.L. Schoff. 1963. Influence of different mulching materials upon the soil environment. Proc. Am. Soc. Hortic. Sci. 82:69-76.

Watson, G.W. 1988. Organic mulch and grass competition influence tree root development. J. Arboric. 14(8): 200-203.

Acknowledgements. We are grateful for the additional financial support for this study from the Florida Department of Agriculture and Consumer Services' 1997 Urban and Community Forestry Grant Program. Without their support this study would not have been possible. We are thankful to Joe Wolf at Gainesville Regional Utility for repeatedly providing us with fresh utility mulch. In addition, we would like to thank Eliana Binelli, David Geller, and David Noletti for providing invaluable field and laboratory analysis and assistance. This is Florida Agricultural Experiment Station Journal Series \#R-06631 of the Institute of Food and Agricultural Sciences, University of Florida, Gainesville, FL 32611.

\author{
${ }^{1 *}$ Professor \\ ${ }^{2}$ Biologist \\ ${ }^{3}$ Graduate Student \\ School of Forest Resources and Conservation \\ University of Florida \\ P.O. Box 110410 \\ Gainesville, Florida 32611-0410 \\ ${ }^{*}$ Corresponding author
}


Résumé. Le paillis joue un rôle important en paysagement en maintenant le taux d'humidité du sol, en réduisant la compétition végétale, en modérant les fluctuations de température du sol et en diminuant l'érosion du sol. Par contre, il y a très peu d'informations disponibles pour aider le consommateur sur le choix de type de paillis à faire. Cette étude a comparé six paillis: paillis de cyprès, paillis d'eucalyptus, écorce de pin, aiguilles de pin, paillis de melaleuca et paillis de copeaux d'élagage. Les paillis d'eucalyptus et de copeaux d'élagage avaient le plus haut taux de décomposition après un an (21 et 32\%) alors qu'entre 3 et $7 \%$ des autres paillis l'étaient. Les taux de lignine et de lignine-azote étaient corrélés négativement avec la décomposition; les valeurs élevées produisaient une faible décomposition. Le taux de respiration en hiver des paillis d'eucalyptus et de copeaux d'élagage était élevé, et il était positivement corrélée avec la décomposition. Le paillis d'écorce de pin s'affaissait de $2 \mathrm{~cm}$ environ. La composition nutritive des paillis était significativement différente; le paillis de copeaux d'élagage avait les plus riches taux de calcium $(\mathrm{Ca})$, magnésium $(\mathrm{Mg})$, azote $(\mathrm{N})$, phosphore $(\mathrm{P})$ et potassium $(\mathrm{K})$. Le paillis d'écorce de pin était élevé en $\mathrm{N}$ et $\mathrm{P}$. Les sols sous les paillis étaient les plus acidifiés avec les aiguilles de pin (de 5,0 à 4,4), suivi de l'écorce de pin et du cyprès. Selon un test standard d'allélopathie, tous les paillis frais inhibaient la germination des graines de laitue; même si la concentration était variable, tous les paillis renfermaient des composés hydroxyl-aromatiques pouvant avoir causé ces effets allélopathiques. Après neuf mois et un an, les paillis d'aiguilles de pin et de copeaux d'élagage produisaient encore des effets allélopathiques sur la germination. Les paillis de cyprès, de melaleuca et d'écorce de pin conservaient leur couleur un an après tandis que les trois autres prenaient une teinte gris-rosée.

Zusammenfassung. Mulche spielen eine wichtige Rolle im Landschaftsbau, um Bodenfeuchtigkeit $z u$ erhalten, Begleitvegetation zu unterdrücken, Bodentemperaturen abzupuffern und Bodenerosion zu reduzieren. Trotzdem gibt es wenig Information für den Nutzer, welche dieser Mulche wie einzusetzen sind. Diese Studie vergleicht 6 Mulche: Zypresse, Eukalyptus, Kiefernrinde, Kiefernnadeln, Melaleuka, und einen Mulch aus Grünflächenschnitt (GRU). Eukalyptus und GRU dekompostierten am schnellsten nach einem Jahr (21\% und $32 \%$ ), während von den anderen nur 3-7 \% zerfielen. Lignin und das Lignin : Stickstoff-Verhältnis standen in negativer Relation zur Dekompostierung, d.h. hohe Raten resutierten in niedriger Dekompostierung. Die Respiration im Winter von Eukalyptus und GRU war sehr hoch und war positiv korreliert mit der Dekompostierung. Der Kiefernnadelmulch sank um schätzungsweise $2 \mathrm{~cm}$ ein.
Die Nährstoffzusammensetzung der Mulche war sehr unterschiedlich, wobei der GRU-Mulch die höchsten Werte an Kalzium (Ca), Magnesium $(\mathrm{Mg})$, Stickstoff $(\mathrm{N})$, Phosphor (P) und Kalium (K). Die Kiefernnadeln hatten einen hohen Gehalt von $\mathrm{N}$ und P. Die Böden unter den Mulchen versauerten am meisten unter Kifernnadelen (von 5,0 bis 4,4), gefolgt von Kiefernrinde und Zypresse. In einem Standardtest zur Allelopathie hemmten alle frischen Mulche die Keimung von Salat und obwohl alle in unterschiedlicher Konzentration, so hatten doch alle Mulche wasserlösliche, aromatische Komponenten, die diese allelopathischen Effekte verursacht haben könnten. Nach neun Monaten und einem Jahr zeigten Kiefernnadeln und GRU immer noch allelopathische Auswirkung auf die Keimung. Zypresse, Melaleuka und Kiefernrinde behielten ihre Farbe nach einem Jahr, während die anderen Mulche zu einem rosa-grauen Farbton wechselten.

Resumen. El mulch juega un importante papel en el paisaje al retener la humedad del suelo, amortiguar su temperatura, disminuir su erosión y reducir la vegetación competidora. Sin embargo, existe poca información para ayudar a los consumidores a decidir qué mulches usar. Este estudio comparó seis mulches: ciprés, eucalipto, corteza de pino, agujas de pino, melaleuca y desechos de poda (GRU). Los mulches de eucalipto y GRU tuvieron la más alta descomposición después de un año ( 21 y $32 \%$ ), mientras que sólo de 3 a $7 \%$ de los otros mulches se pudrieron. Las relaciones de lignina y lignina/nitrógeno estuvieron correlacionadas negativamente con la descomposición; altos valores resultaron en baja descomposición. La respiración en invierno de ambos mulches, eucalipto y GRU, fue alta y la respiración fue correlacionada positivamente con la descomposición. El mulch de aguja de pino se bajó aproximadamente $2 \mathrm{~cm}$. La composición de nutrimentos de los mulches fue significativamente diferente, con el mulch GRU se tuvieron más altos niveles de calcio $(\mathrm{Ca})$, magnesio $(\mathrm{Mg})$, nitrógeno $(\mathrm{N})$, fósforo $(\mathrm{P})$ y potasio $(\mathrm{K})$. El mulch de aguja de pino fue alto en $\mathrm{N}$ y $\mathrm{P}$. Los suelos bajo los mulches fueron acidificados en mayor medida por el mulch de aguja de pino (de 5.0 a 4.4), seguido por el mulch de corteza de pino y de ciprés. En una prueba estándar de alelopatía, todos los mulches frescos inhibieron la germinación de semilla de lechuga $\mathrm{y}$, a pesar de la variación en concentración, todos los mulches contenian compuestos hidroxilados aromáticos, lo cual pudo haber causado estos efectos alelopáticos. Después de nueve meses y un año, el mulch de aguja de pino y el GRU todavia exhibieron efectos alelopáticos sobre la germinación. Los mulches de ciprés, melaleuca y corteza de pino retuvieron su color después de un año, mientras que los otros tres cambiaron a un gris rosáceo. 